\title{
ESPERIMENTASI PENDEKATAN PEMBELAJARAN PENDIDIKAN MATEMATIKA REALISTIK DAN PEMBELAJARAN SAINTIFIK TERHADAP HASIL BELAJAR MATEMATIKA DITINJAU DARI GAYA BELAJAR SISWA KELAS VIII SMPN 25 BATAM TAHUN PELAJARAN 2015/2016
}

\author{
${ }^{1}$ Yudhi Hanggara, ${ }^{2}$ Rio Mardani Suhardi \\ ${ }^{1}$ Dosen Program Studi Pendidikan Matematika FKIP Universitas Riau Kepulauan, Batam \\ ${ }^{2}$ Mahasiswa Program Studi Pendidikan Matematika FKIP Universitas Riau Kepulauan, \\ Batam
}

Korespondensi: Program Studi Pendidikan Matematika FKIP Universitas Riau Kepulauan, Batam. E-mail: yudhihanggara@gmail.com

\begin{abstract}
Abstrak
Penelitian ini bertujuan untuk mengetahui: (1) Perbedaan hasil belajar antara siswa yang diberi perlakuan pendekatan pembelajaran Pendidikan Matematika Realistik dengan pendekatan pembelajaran Saintifik. (2) Perbedaan hasil belajar antara siswa yang memiliki gaya belajar visual, auditori, dan kinestetik. (3) Interaksi antara pendekatan pembelajaran (PMR dan Saintifik) dengan gaya belajar siswa.

Jenis penelitian ini adalah penelitian eksperimental semu dengan desain faktorial $2 \times 3$. Populasi penelitian ini adalah seluruh siswa SMPN 25 Batam Kelas VIII tahun pelajaran 2015/2016. Pengambilan sampel dilakukan dengan teknik Cluster Random Sampling. Sampel dalam penelitian ini sebanyak dua kelas yaitu kelas ekperimen dan kelas kontrol. Instrumen yang digunakan untuk mengumpulkan data adalah nilai tes ujian tengah semester I, angket gaya belajar, dan tes hasil belajar matematika. Uji prasyarat meliputi uji normalitas menggunakan metode Lilliefors dan uji homogenitas menggunakan metode Bartlett. Dengan $\alpha=0,05$, diperoleh kesimpulan bahwa sampel berasal dari populasi yang berdistribusi normal dan mempunyai variansi yang homogen. Uji keseimbangan terhadap data kemampuan awal matematika menggunakan analisis variansi satu jalan dengan sel tak sama diperoleh kesimpulan bahwa kedua kelas eksperimen mempunyai kemampuan awal matematika yang seimbang. Pengujian hipotesis menggunakan analisis variansi dua jalan dengan sel tak sama.

Hasil penelitian menunjukkan: (1) Pendekatan pembelajaran Pendidikan Matematika Realistik menghasilkan hasil belajar lebih baik daripada pendekatan pembelajaran Saintifik . (2) Hasil belajar siswa dengan gaya belajar auditori lebih baik dari pada hasil belajar siswa dengan gaya belajar visual dan kinestetik, kemudian hasil belajar siswa dengan gaya belajar visual sama baiknya dnegan hasil belajar siswa dengan gaya belajar kinestetik (3) Tidak terdapat interaksi antara pendekatan pembelajaran (PMR dan saintifik) dengan gaya belajar siswa.
\end{abstract}

Kata Kunci: pendidikan matematika realistik, pembelajaran saintifik, gaya belajar, hasil belajar matematika

\begin{abstract}
This research aims to find out: (1) The difference between the student learning outcomes who were given the treatment by Realistic Mathematics Education (RME) and Scientific Learning. (2) The difference between the student learning outcomes who have
\end{abstract}


auditory, visual, and kinesthetic Learning Styles. (3) Interaction between Learning Approches (PMR and Scientific) and students Learning Styles.

This research was quasi-experimental research with a $2 \times 3$ factorial design. The population of research was all students in $8^{\text {th }}$ grade of SMPN 25 Batam for 2015/2016 academic year.The sample in this research was devided into two groups: the experimental and the control class. The instrument used to collect the data was $1^{\text {st }}$ mid-semester mathematics exam result, learning styles questionnaire, and the test result of learning mathematics. The prerequisite test included the population normality test using Lilliefors method and homogeneity test of population variance using Bartlett method. With $\alpha=0.05$, it could be concluded that the sample derived from the population distributed normally and having homogeneous variance. The equilibrium test was done using one-way analysis of variance with different cell indicating that the two groups had equal prior competency of mathematics. The hypothesis testing was done using a two-way analysis of variance with different cell.

The result of research showed that : (1) The Realistic Mathematics Education approach's learnig outcomes was better than the Scientific Learning approach did. (2) The students with auditory learning style had learning outcome better than those with visual learning style did, the students with visual learning style had learning outcomes w better than those with kinesthetic learning style did, and the students with visual learning style had learning outcome as good as those with kinesthetic learning style did. (3) There is no interaction between the learning approaches and students' learning style to students' learning outcomes, subject focused in geometry.

Keywords: Realistik Mathematics Education, Scientific Learning, Learning Styles, Mathematics learning outcomes.

\section{PENDAHULUAN}

Matematika merupakan ilmu yang memiliki peranan penting yang bersifat universal dan realistis. Universal berarti matematika merupakan ilmu induk yang memiliki peranan penting yakni dapat diaplikasikan pada cabang ilmu lainnya. Matematika merupakan ilmu realistis yang pada dasarnya bermula dari kehidupan yang nyata. Selayaknya dimulai dari suatu permasalahan nyata yang bersumber dari ilustrasi yang dekat dan mampu dijangkau siswa, kemudian disederhanakan dalam rumus-rumus matematis untuk dapat diaplikasikan siswa dalam pembelajaran matematika di sekolah.

Berdasarkan hasil observasi yang peneliti lakukan pada bulan Agustus - September 2015 di SMP Negeri 25 Batam pada siswa kelas VIII. Pada umumnya guru hanya memberikan materi pembelajaran, dilanjutkan dengan siswa mengerjakan lembar aktivitas secara individu, kemudian guru meminta siswa yang bisa untuk menuliskan jawaban yang benar di depan kelas. Beberapa siswa yang belum memahami materi yang disampaikan guru kurang memiliki keberanian untuk bertanya, sehingga menyebabkan beberapa siswa yang kurang pandai menjadi cenderung pasif selama pembelajaran berlangsung. Selain itu, selama proses kegiatan pembelajaran siswa cenderung hanya memahami bagaimana menyelesaikan 
suatu permasalahan dengan mengaplikasikan konsep-konsep pembelajaran yang diberikan, tanpa memahami bagaimana dan kenapa konsep-konsep tersebut ada. Sehingga hal ini menyebabkan pembelajaran matematika kurang bermakna bagi siswa.

Permasalahan lain yang terlihat adalah hasil belajar siswa yang masih rendah, hal ini terlihat dari persentase ketercapaian KKM nilai ujian tengah semester siswa kelas VIII di SMP Negeri 25 Batam yang masih di bawah persentase yang diharapkan. Dari sembilan kelas tidak ada satupun kelas yang persentase ketuntasan KKM yang melampaui persentase ketuntasan KKM yang diharapkan yaitu $75 \%$. Penyebab rendahnya hasil belajar matematika siswa kelas VIII salah satunya adalah pendekatan pembelajaran yang kurang sesuai dengan karakteristik siswa maupun materi pokok yang disampaikan, sehingga dapat menimbulkan kejenuhan, monoton dan siswa yang cenderung pasif kurang memiliki minat untuk belajar. Padahal pendekatan pembelajaran merupakan faktor utama yang mempengaruhi hasil belajar, terlebih lagi untuk pembelajaran matematika di sekolah.

Dalam penelitian ini, dipilih suatu pendekatan pembelajaran yang mampu meningkatkan hasil belajar siswa yaitu pendekatan pembelajaran pendidikan matematika realistik (PMR). Freudenthal (1991) dalam Aryadi (2012) menjelaskan bahwa pendekatan pembelajaran pendidikan matematika realistik dikarenakan kebermaknaan konsep merupakan konsep utama dari pendidikan matematika, proses belajar akan terjadi jika pengetahuan yang dipelajari bermakna bagi siswa. Pada penelitian Windarti (2013) menyimpulkan bahwa pembelajaran pendidikan matematika realistik dapat meningkatkan hasil belajar siswa kelas VIII di SMP Negeri 25 Batam Tahun Pelajaran 2013/2014.

Freudenthal (1973) dalam Oh Nam Kwon (2001) mengatakan "Mathematics is a human activity". Artinya matematika merupakan suatu bentuk aktivitas manusia dimana persolan-persoalan yang terdapat pada matematika secara umum diperoleh melalui aktivitas manusia dalam kehidupan sehari-hari. Istilah tersebutlah yang melandasi perkembangan pendidikan matematika realistik. Treffers dalam dalam Van den Heuvel-Panhuizen (1996) merumuskan lima karakteristik pendidikan matematika realistik antara lain: (1) Penggunaan konteks; (2) Penggunaan model untuk matematika progresif; (3) Pemanfaatan hasil konstruksi siswa; (4) Interaktivitas; (4) Keterpaduan konsep matematika.

Seiring dengan berlakunya kurikulum 2013 yang menempatkan pendekatan saintifik sebagai pendekatan pembelajaran yang diterapkan di sekolah, begitu pula di SMP Negeri 25 Batam. Oleh karena itu penerapan pendekatan saintifik juga dijadikan sebagai variabel yang diteliti pada penelitian ini. Adapun langkah-langkah pendekatan pembelajaran saintifik (Kemendikbud, 2014) meliputi: (1) Mengamati/observing; (2) Menanya/questioning; (3) 
Mengumpulkan informasi; (3) Mengumpulkan informasi; (4) Menalar/Associating;

Mencoba/Experimenting.

Selain menggunakan dua pendekatan pembelajaran untuk melihat perbandingan hasil belajar matematika siswa, peneliti juga meninjau gaya belajar sebagai faktor luaran yang mempengaruhi keberhasilan belajar matematika. Hal ini sejalan dengan teori yang dikemukakan oleh Kolb dalam Ghufron (2014: 42) yang menyatakan bahwa gaya belajar merupakan suatu pendekatan yang menjelaskan bagaimana cara siswa dalam menyerap informasi dari pembelajaran secara konsisten.

Hasil wawancara yang peneliti lakukan bersama Ibu Erna Arita, S.Pd selaku guru matematika kelas VIII di SMP Negeri 25 Batam pada tanggal 25 Desember 2015 mengatakan bahwa setiap siswa memiliki cara yang khas selama proses pembelajaran berlangsung. Ada siswa yang kurang cepat dalam memahami materi yang disampaikan oleh guru, sehingga meminta temannya yang pandai untuk menerangkan kembali apa yang telah disampaikan oleh guru. Ada siswa yang konsenterasi belajarnya mudah terganggu akibat perilaku temannya yang ribut dan ada pula siswa yang menggerakkan bibir (bersuara) ketika membaca soal latihan yang ada di papan tulis maupun buku catatan. Kebiasaan yang berbeda ini menunjukkan siswa memiliki kecenderungan gaya belajar yang berbeda.

Menurut teori yang dikemukakan oleh Bandler dan Grinder (1981) dalam DePorter (2010: 122-124) gaya belajar ada 3 yakni belajar visual, auditori, dan kinestetik, dan setiap individu cenderung pada salah satu dari ketiga gaya belajar tersebut. Teori tersebut memiliki keterkaitan dengan masalah yang didapatkan dari hasil wawancara peneliti, sehingga gaya belajar visual, auditori, dan kinestetik peneliti gunakan sebagai salah satu variabel yang juga zditeliti pada penelitian ini.

Penelitian yang dilakukan Nur (2012), menjelaskan bahwa prestasi belajar matematika siswa yang mempunyai gaya belajar auditori lebih baik daripada prestasi belajar matematika siswa yang mempunyai gaya belajar visual maupun kinestetik, sementara prestasi belajar matematika antara siswa yang mempunyai gaya belajar visual dan siswa yang mempunyai gaya belajar kinestetik adalah sama, berdasarkan hasil penelitian siswa diharapkan mengoptimalkan kecenderungan gaya belajar yang dimilikinya agar meningkatkan hasil belajar.

Tujuan yang ingin dicapai dalam penelitian ini yaitu untuk mengetahui: (1) Perbedaan hasil belajar antara siswa yang diberi perlakuan pendekatan pembelajaran Pendidikan Matematika Realistik dengan pendekatan pembelajaran Saintifik; (2) Perbedaan hasil belajar 
antara siswa yang memiliki gaya belajar visual, auditori, dan kinestetik; (3) Interaksi antara pendekatan pembelajaran (PMR dan Saintifik) dengan gaya belajar siswa.

\section{METODE PENELITIAN}

Jenis penelitian ini adalah penelitian quasi eksperimen dengan desain factorial $2 \times 3$. Variabel bebasnya adalah pendekatan pembelajaran (PMR dan Saintifik) dan gaya belajar siswa (visual, auditori, dan kinestetik), serta variabel terikatnya adalah hasil belajar matematika siswa pada materi pokok bangun ruang sisi datar.

Populasi penelitian ini adalah seluruh siswa kelas VIII SMP Negeri 25 Batam. Pengambilan sampel dilakukan dengan teknik cluster random sampling. Sampel dalam penelitian ini berjumlah 88 siswa, yang terdiri atas 44 siswa kelas eksperimen dan 44 siswa kelas kontrol. Kemudian kedua kelas dilakukan uji keseimbangan rerata kemampuan awal pada nilai ulangan tengah semester ganjil mata pelajaran matematika tahun pelajaran 2015/2016. Adapun uji keseimbangan rerata kemampuan awal menggunakan uji ANAVA satu jalan dengan uji prasyarat data hasruss berdistribusi normal dan memiliki varian yang homogen. Hasil uji keseimbangan rerata kemampuan awal menunjukkan bahwa kedua kelas memiliki kemapuan awal yang seimbang.

Teknik pengumpulan data yang digunakan dalam penelitian ini adalah tes, angket, dan dokumentasi. Tes digunakan untuk mengetahui hasil belajar siswa, angket digunakan untuk mengetahui kecenderungan gaya belajar siswa, dan dokumentasi digunakan untuk mendapatkan nilai ujian tengah semester dan data siswa. Instrumen penelitian yang digunakan berupa tes uraian yang digunakan untuk mengukur hasil belajar matematika siswa pada materi pokok bangun ruang sisi datar, angket gaya belajar siswa untuk mengetahui kecenderungan gaya belajar siswa.

Analisis instrumen penelitian yang digunakan meliputi analisis instrumen tes hasil belajar matematika dan angket gaya belajar siswa. Untuk tes hasil belajar matematika menggunakan analisis instrumen yang meliputi uji validitas, tingkat kesukaran, daya pembeda, dan uji reliabilitas. Sementara itu, untuk angket gaya belajar siswa dilakukan uji validitas dan reliabilitas. Uji validitas tes dan angket menggunakan validitas isi dan konstruk, dimana validitas isi tes menggunakan Content Validity Ratio (CVR) yang melibatkan 7 orang Subject Matter Expert (SME), validitas isi angket melibatkan 3 orang validator, kemudian dilanjutkan dengan uji validitas konstruk tes dan angket menggunakan rumus korelasi product moment. Untuk uji reliabilitas tes dan angket menggunakan rumus koefesian Alpha Cronbach. 
Teknik analisis data yang digunakan untuk menguji hipotesis penelitian ini adalah ANAVA dua jalan dengan sel tak sama. Dimana sebelum itu dilakukan uji prasyarat ANAVA yang meliputi uji normalitas menggunakan uji Lilliefors dan uji homogenitas menggunakan uji Barlette. Apabila setelah dilakukan uji hipotesis terdapat hipotesis nol yang ditolak, maka dilanjutkan dengan uji lanjut pasca ANAVA yaitu uji komparasi ganda dengan metode Scheffee.

\section{HASIL PENELITIAN DAN PEMBAHASAN}

Tabel 1.

Rangkuman Rerata Antar Sel dan Rerata Antar Marginal

\begin{tabular}{ccccc}
\hline & \multicolumn{3}{c}{ Gaya Belajar Siswa } & Rerata \\
& Visual $\left(\mathrm{b}_{1}\right)$ & Auditori $\left(\mathrm{b}_{2}\right)$ & Kinestetik $\left(\mathrm{b}_{3}\right)$ & Marginal \\
\hline PMR $\left(\mathrm{a}_{1}\right)$ & 67,62 & 81,94 & 65,57 & 72,66 \\
Saintifik $\left(\mathrm{a}_{2}\right)$ & 61,16 & 70,32 & 53,83 & 64,11 \\
Rerata Marginal & 64,55 & 75,63 & 60,15 & \\
\hline
\end{tabular}

Tabel 2.

Rangkuman Analisis Variansi Dua Jalan dengan Sel Tak Sama

\begin{tabular}{lcccccc}
\hline \multicolumn{1}{c}{ Sumber } & JK & Dk & RK & $\mathrm{F}_{\text {obs }}$ & $\mathrm{F}_{\text {tabel }}$ & Keputusan Uji \\
\hline Pendekatan & 1694,079 & 1 & 1694,079 & 8,032 & 3,96 & $\mathrm{H}_{0}$ ditolak \\
Pembelajaran (A) & & & & & & \\
Gaya Belajar (B) & 3275,014 & 2 & 1637,51 & 7,764 & 3,11 & $\mathrm{H}_{0}$ ditolak \\
Interaksi (AB) & 103,863 & 2 & 210,915 & 0,246 & 3,11 & $\mathrm{H}_{0}$ diterima \\
Galat ( G ) & 17295,070 & 82 & 210,915 & & - & - \\
Total & 22368,026 & 87 & - & & - & - \\
\hline
\end{tabular}

Berdasarkan Tabel 26 tampak bahwa:

a. Pada efek utama $\mathrm{A}$ (pendekatan pembelajaran), nilai statistik uji $\mathrm{F}_{\mathrm{a}}=8,032$ dan $\mathrm{F}_{\text {tabel }}=$ 3,96. Ternyata $F_{a}>F_{\text {tabel. }}$ Hal ini berarti $F_{a} \in D K$. Dengan demikian $\mathrm{H}_{0 A}$ ditolak. Hal ini berarti pada tingkat signifikansi $\alpha=0,05$ terdapat perbedaan efektifitas pendekatan pembelajaran Pendidikan Matematika Realistik dan Saintifik.

b. Pada efek utama $B$ (gaya belajar), nilai statistik uji $F_{b}=7,764$ dan $F_{\text {tabel }}=3,11$. Ternyata $F_{b}$ $>\mathrm{F}_{\text {tabel. }}$ Hal ini berarti $\mathrm{F}_{\mathrm{b}} \in \mathrm{DK}$. Dengan demikian $\mathrm{H}_{0 \mathrm{~B}}$ ditolak. Hal ini berarti pada tingkat 
signifikansi $\alpha=0,05$ terdapat perbedaan hasil belajar antara kelompok siswa dengan gaya belajar visual, auditori dan kinestetik.

c. Pada efek interaksi $\mathrm{AB}$ (pendekatan pembelajaran dan gaya belajar), nilai statistik uji $\mathrm{F}_{\mathrm{ab}}=$ 0,246 dan $\mathrm{F}_{\text {tabel }}=3,11$. Ternyata $\mathrm{F}_{\mathrm{ab}}<\mathrm{F}_{\text {tabel. }}$ Hal ini berarti $\mathrm{F}_{\mathrm{ab}} \notin \mathrm{DK}$, Dengan demikian $\mathrm{H}_{0 \mathrm{AB}}$ diterima. Hal ini berarti tidak terdapat interaksi antara pendekatan pembelajaran dengan gaya belajar siswa.

Berdasarkan hasil perhitungan ANAVA dua jalan 2x3 dengan sel tak sama, diketahui bahwa $\mathrm{H}_{0 \mathrm{~A}}$ ditolak, sementara $\mathrm{H}_{0 \mathrm{AB}}$ diterima, sehingga perlu dilakukan uji komparasi ganda yang bertujuan untuk melakukan pelacakan terhadap perbedaan rerata antar baris dan antar kolom. Untuk $\mathrm{H}_{0 \mathrm{~A}}$, Perlu diperhatikan bahwa variabel pendekatan pembelajaran hanya memiliki dua faktor yaitu faktor $\mathrm{a}_{1}$ (PMR) dan $\mathrm{a}_{2}$ (saintifik), berdasarkan rerata marginal menunjukkan bahwa hasil belajar siswa dengan pendekatan pembelajaran PMR lebih baik daripada hasil belajar siswa dengan pendekatan pembelajaran saintifik. Apabila dilakukan uji komparasi ganda pada rerata marginal pendekatan pembelajaran, maka hipotesis nolnya juga akan ditolak seperti yang sebelumnya telah diperoleh pada uji ANAVA (Budiyono, 2015: 220).

Tabel 3.

Rangkuman Hasil Uji Komparasi Rearata Antar Kolom

\begin{tabular}{cccc}
\hline Komparasi & $F_{\text {hitung }}$ & $F_{\text {kritik }}$ & Keputusan Uji \\
\hline$\mu_{\cdot 1}=\mu \cdot 2$ & 10,247 & 6,22 & $\mathrm{H}_{0}$ ditolak \\
$\mu_{\cdot 1}=\mu \cdot 3$ & 0,849 & 6,22 & $\mathrm{H}_{0}$ diterima \\
$\mu_{\cdot 2}=\mu \cdot 3$ & 10,157 & 6,22 & $\mathrm{H}_{0}$ ditolak \\
\hline
\end{tabular}

Berdasarkan hasil uji komparasi rataan antar kolom pada masing-masing gaya belajar siswa, dengan taraf signifikansi 0,05 diperoleh bahwa:

a. $\mathrm{H}_{0}$ yang pertama, yaitu $\mu_{.1}=\mu_{.2}$ ditolak. Hal ini berarti bahwa terdapat perbedaan hasil belajar matematika antara siswa yang memiliki gaya belajar visual dengan siswa yang memiliki gaya belajar auditori. Berdasarkan Tabel 27, rerata marginal hasil belajar matematika siswa yang yang memiliki gaya belajar visual, yakni 64,55 lebih kecil dibandingkan rerata marginal hasil belajar matematika siswa yang memiliki gaya belajar 
auditori, yakni 75,63. Dengan demikian, diperoleh kesimpulan bahwa hasil belajar matematika siswa yang memiliki gaya belajar auditori lebih baik daripada hasil belajar matematika siswa yang memiliki gaya belajar visual.

b. $\mathrm{H}_{0}$ yang kedua, $\mu_{.1}=\mu_{\cdot 3}$ diterima. Hal ini berarti bahwa tidak terdapat perbedaan hasil belajar matematika antara siswa yang memiliki gaya belajar visual dengan siswa yang memiliki gaya belajar kinestetik. Dengan demikian, diperoleh kesimpulan bahwa hasil belajar matematika siswa yang memiliki gaya belajar visual sama baiknya dengan hasil belajar matematika siswa yang memiliki gaya belajar kinestetik.

c. $\mathrm{H}_{0}$ yang pertama, yaitu $\mu_{\cdot 2}=\mu_{\cdot 3}$ ditolak. Hal ini berarti bahwa terdapat perbedaan hasil belajar matematika antara siswa yang memiliki gaya belajar auditori dengan siswa yang memiliki gaya belajar kinestetik. Berdasarkan Tabel 27, rerata marginal hasil belajar matematika siswa yang yang memiliki gaya belajar auditori, yakni 75,63 lebih besar dibandingkan rerata marginal hasil belajar matematika siswa yang memiliki gaya belajar kinestetik, yakni 60,15. Dengan demikian, diperoleh kesimpulan bahwa hasil belajar matematika siswa yang memiliki gaya belajar auditori lebih baik daripada hasil belajar matematika siswa yang memiliki gaya belajar kinestetik.

\section{Pembahasan}

\section{Hipotesis pertama}

Kelas eksperimen pada penelitian ini memperoleh pendekatan pembelajaran Pendidikan Matematika Realistik (PMR). Pendekatan pembelajaran Pendidikan Matematika Realistik merupakan pendekatan pembelajaran yang memiliki karakteristik penggunaan konteks, model matematika progresif, pemanfaatan hasil konstruksi siswa, interaktivitas, serta keterpaduan konsep matematika (Aryadi, 2012). Sehingga proses belajar mengajar dapat berjalan dengan maksimal karena selain pembelajaran berpusat pada siswa, pendekatan pembelajaran Pendidikan Matematika Realistik juga memberikan ruang yang cukup bagi siswa untuk lebih memahami materi yang dipelajari.

Pembelajaran dengan pendekatan PMR memberikan kesempatan kepada siswa untuk menemukan sendiri konsep matematika. Hal ini terkait dengan pendekatan PMR yang 
memfasilitasi siswa untuk mengidentifikasi permasalahan sampai membuat kesimpulan (Istikori, 2013). Akan tetapi menurut Ruseffendi dalam Harry (2014) dilihat dari segi umur anak di SMP, sebagian dari pada mereka tahap berpikirnya belum masuk ke dalam tahap operasi formal, kemungkinan besar perkembangan intelektualnya masih tahap operasi konkrit. Tahap berpikir formal nampaknya tepat dikenakan kepada siswa SMP kelas IX keatas. Oleh karena itu siswa pada kelas eksperimen yaitu siswa kelas VIII masih memerlukan bantuan oleh guru untuk membentuk konsep matematika formal.

Kelas kontrol pada penelitian ini memperoleh pembelajaran Saintifik. Pendekatan pembelajaran Saintifik identik dengan kegiatan mengamati, menanya, mengumpulkan informasi, menganalisis, hingga mengkomunikasikan (Kemendikbud, 2014). Akan tetapi selama penelitian berlangsung terdapat beberapa hal yang menyebabkan kurang efektifnya penerapan pembelajaran saintifik. Seperti pada kegiatan mengamati, hanya beberapa siswa yang melakukan kegiatan mengamati sedangkan sebagian siswa lainnya kurang memperhatikan. Selain itu pada kegiatan menanya, secara umum pertanyaan maupun jawaban lebih cenderung dilakukan oleh siswa yang pandai saja, sedangkan siswa yang kurang pandai terlihat pasif.

Berdasarkan hasil uji hipotesis pertama penelitian ini, pendekatan pembelajaran PMR memberikan hasil belajar yang lebih baik dibandingkan dengan pendekatan pembelajaran Saintifik. Hal ini dapat terlihat dari rerata marginal hasil belajar matematika siswa yang memperoleh pendekatan pembelajaran Pendidikan Matematika Realistik, yakni 72,50 lebih besar dibandingkan rerata marginal hasil belajar matematika siswa yang memperoleh pendekatan pembelajaran Saintifik, yakni 64,11.

\section{Hipotesis Kedua}

Setiap siswa memiliki ciri masing-masing dalam menentukan bagaimana cara belajar yang disukai untuk kemudian diterapkan. Cara khas belajar siswa tersebut lebih dikenal dengan istilah gaya belajar ( Gilakjani, 2012).

Gaya belajar siswa dapat dikategorikan menjadi gaya belajar visual, auditori, dan kinestetik, dan setiap individu cenderung pada salah satu dari ketiga gaya belajar tersebut (De Porter, 2010). Gaya belajar ini sangat dipengaruhi oleh faktor kebiasaan siswa dalam berinteraksi dengan lingkungannya termasuk guru dalam mengajar di kelas. Pemahaman tersebut dijadikan salah satu pedoman untuk mengetahui kecenderungan gaya belajar siswa apakah visual, auditori, atau kinestetik. Permasalahannya adalah bagaimana guru dapat mengolah potensi siswa dengan gaya belajar siswa sedemikian rupa agar siswa itu dapat termotivasi untuk menyukai pembelajaran matematika di kelas. 
Siswa dengan gaya belajar visual memiliki karakteristik mengingat dengan gambar (DePorter, 2010). Selama proses belajar mengajar berlangsung, siswa dengan gaya belajar visual cenderung melihat dulu buktinya untuk kemudian mempercayainya. Maksudnya adalah siswa dengan gaya belajar visual cenderung meminta guru untuk menyelesaikan sebuah contoh soal sehingga mereka dapat memahami apa yang sedang mereka pelajari dengan melihat. Permasalahannya adalah guru tidak harus selalu memandu siswa dalam mengerjakan seluruh contoh soal, sebagaimana kurikulum 2013 yang berbasis student' self concept untuk diterapkan oleh guru pada proses pembelajaran di kelas (Kemendikbud, 2014).

Kemudian siswa dengan gaya belajar auditori mempunyai kemampuan untuk menyerap informasi melalui indra pendengaran. Siswa yang mempunyai tipe gaya belajar auditori dapat belajar lebih cepat dengan menggunakan diskusi verbal serta mendengarkan apa yang guru sampaikan (DePorter, 2010). Kondisi ini sangatlah tepat dengan diterapkannya pendekatan pembelajaran baik PMR maupun Saintifik dengan metode diskusi kelompok selama penelitian, sehingga siswa dengan gaya belajar auditori memberikan hasil belajar yang lebih baik daripada siswa dengan gaya belajar visual maupun kinestetik.

Berbeda dengan siswa yang memiliki gaya belajar kinestetik. Siswa sulit untuk duduk diam berjam-jam karena keinginan mereka untuk beraktivitas sangatlah kuat (DePorter, 2010). Selama penelitian, siswa dengan gaya belajar kinestetik sulit untuk mendengarkan arahan dari guru dan lebih fokus dengan kegiatannya sendiri. Faktor inilah yang menjadi salah satu penyebab kurang efektifnya proses belajar mengajar di kelas.

Hipotesis yang kedua menyatakan bahwa terdapat perbedaan hasil belajar matematika antara siswa yang memiliki tipe gaya belajar visual, auditori, dan kinestetik. Berdasarkan hasil penelitian diperoleh siswa yang memiliki gaya belajar auditori menghasilkan hasil belajar yang lebih baik daripada siswa yang memiliki gaya belajar visual maupun kinestetik. sementara itu siswa yang memiliki gaya belajar visual mempunyai hasil belajar yang sama baiknya dengan siswa yang memiliki gaya belajar kinestetik.

Analisis penelitian ini sejalan dengan penelitian yang diakukan oleh Nur (2010) yang menyimpulkan bahwa siswa yang memiliki gaya belajar auditori menghasilkan hasil belajar yang lebih baik daripada siswa yang memiliki gaya belajar visual maupun kinestetik, sedangkan hasil belajar siswa yang memiliki gaya belajar visual dan kinestetik adalah sama baiknya.

\section{Hipotesis Ketiga}

Hipotesis yang ketiga mengatakan bahwa tidak terdapat interaksi antara pendekatan pembelajaran (PMR dan Saintifik) dengan gaya belajar siswa. Hasil penelitian menunjukkan 
bahwa Hipotesis nol diterima sehingga dapat disimpulkan tidak terdapat interaksi antara pendekatan pembelajaran (PMR dan Saintifik) dengan gaya belajar siswa. Sehingga dapat dinyatakan bahwa karakteristik perbedaan antara pendekatan pembelajaran Pendidikan Matematika Realistik dan pembelajaran Saintifik untuk setiap gaya belajar adalah sama. Karakteristik tersebut tentu saja sama dengan karakteristik marginal perbedaan rerata antar pendekatan pembelajaran. Berdasarkan hasil uji komparasi ganda rerata antar baris (pendekatan pembelajaran), pendekatan pembelajaran Pendidikan Matematika Realistik lebih baik dibandingkan dengan Pembelajaran Saintifik. Karena tidak ada interaksi, maka hal tersebut berlaku juga pada tiap pendekatan pembelajaran yang siswanya memiliki gaya belajar visual; dalam arti pada siswa yang memiliki gaya belajar visual, pendekatan pembelajaran Pendidikan Matematika Realistik lebih baik daripada pendekatan pembelajaran Saintifik. Demikian pula halnya kalau hanya diperhatikan siswa yang memiliki gaya belajar auditori atau gaya belajar kinestetik saja.

Berdasarkan hasil uji komparasi ganda rerata antar kolom (gaya belajar siswa), gaya belajar auditori lebih baik dibandingkan dengan gaya belajar visual, gaya belajar auditori lebih baik dibandingkan dengan gaya belajar kinestetik dan gaya belajar visual sama baiknya dengan gaya belajar kinestetik. Karena tidak ada interaksi, maka hal tersebut berlaku juga untuk tiap gaya belajar pada masing-masing pendekatan pembelajaran; dalam arti, pada masing-masing pendekatan pembelajaran PMR dan Pendekatan pembelajaran Saintifik, siswa yang memiliki gaya belajar auditori lebih baik daripada siswa yang memiliki gaya belajar visual maupun kinestetik dan siswa yang memiliki gaya belajar visual sama baiknya dengan siswa yang memiliki gaya belajar kinestetik.

Jadi, kalau interaksi antara variabel bebas tidak ada, maka tidak perlu dilakukan uji lanjut antar sel pada kolom/baris yang sama. Kesimpulan perbandingan rerata antar sel mengacu kepada kesimpulan perbandingan rerata marginalnya.

\section{KESIMPULAN DAN SARAN}

Berdasarkan hasil penelitian dan pembahasan, disimpulkan bahwa pada siswa kelas VIII SMP Negeri 25 Batam, khususnya untuk materi pokok bangun ruang sisi datar:

1. Pendekatan pembelajaran Pendidikan Matematika Realistik menghasilkan hasil belajar matematika yang lebih baik daripada pendekatan pembelajaran Saintifik.

2. Siswa yang memiliki gaya belajar auditori memiliki hasil belajar yang lebih baik daripada siswa yang memiliki gaya belajar visual maupun kinestetik, dan siswa yang memiliki gaya 
belajar visual memiliki prestasi belajar yang sama baiknya dengan siswa yang memiliki gaya belajar kinestetik.

3. Siswa yang memiliki gaya belajar visual, auditori dan kinestetik pada pendekatan pembelajaran Pendidikan Matematika Realistik memiliki hasil belajar lebih baik daripada pendekatan pembelajaran Saintifik. Pada pendekatan pembelajaran Pendidikan Matematika Realistik dan Saintifik, siswa yang memiliki gaya belajar auditori memiliki hasil belajar lebih baik daripada siswa yang memiliki gaya belajar visual dan kinestetik, dan siswa yang memiliki gaya belajar visual memiliki hasil belajar yang sama baiknya dengan siswa yang memiliki gaya belajar kinestetik.

Berdasarkan pemaparan diatas, dapat diakui bahwa pendekatan pembelajaran PMR memberikan hasil belajar matematika siswa yang lebih baik dibandingkan dengan pendekatan pembelajaran saintifik. Kemudian siswa dengan gaya belajar auditori memiliki hasil belajar yang lebih baik dibandingkan dengan siswa dengan gaya belajar visual maupun kinestetik. Oleh karena itu, hendaknya guru harus memahami masing-masing karakteristik gaya belajar siswa dan stategi untuk mengoptimalkannya sebelum menerapkan suatu pendekatan pembelajaran. Dalam hal ini guru harus dapat memilih pendekatan pembelajaran yang sesuai dengan gaya belajar siswa baik visual, auditori, maupun kinestetik, sehingga siswa dapat mengoptimalkan kecenderungan gaya belajarnya untuk mendapatkan hasil belajar matematika yang optimal.

\section{DAFTAR PUSTAKA}

Ariyadi Wijaya. (2012). Pendidikan Matematika Realistik Suatu Alternatif Pendekatan Pembelajaran Matematika. Yogyakarta: Graha Ilmu.

Budiyono. (2015). Statistika Untuk Penelitian. Surakarta: UNS PRESS.

DePorter, B., Reardon, M \& Singer-Nourie, S. (2010). Quantumn Teaching. Bandung: KAIFA.

Gilakjani, A.P. (2012). Visual, Auditory, Kinesthetic Learning Styles and Their Impacts on English Language Teaching. Macrothink Institute, 105.

Jamilah. (2013). Eksperimentasi Pendekatan Pendidikan Matematika Realistik (PMR) Dengan Metode Discovery Learning Pada Materi Pokok Bentuk Aljabar Ditinjau Dari Kemampuan Komunikasi Matematis. Jurnal Universitas Sebelas Maret.

Kemendikbud. (2014). Diklat Guru dalam Rangka Implementasi Kurikulum 2013, Konsep Pendekatan Saintifik.

Nur Ghufron \& Rini Risnawita. (2010). Gaya Belajar Kajian Teoritik. Jogjakarta: Pustaka Pelajar. 
Nur Rohman. (2012). Eksperimentasi Pendekatan Pembelajaran Pendidikan Matematika Realistik dan Problem Based Learning Pada Operasi Bilangan Bulat Ditinjau dari Gaya Belajar Siswa. UNS press.

Oh Nam Kwon. (2002). Conceptualizing The Realistic Mathematics Education Approach in The Teaching and Learning of Ordinary Differential Equations. Ehwa Womans University, Departement of Mathematics Education, Seoul, Korea.

Van den Heuvel-Panhuizen, M. (1996). Assessment and Realistic Mathematic Education. Utrecht: CD- $\beta$ Press, Center for Science and Mathematics Education.

Windarti Dwi Utami. (2013). " Efektivitas Model Realistic mathematics Education (RME) Terhadap Hasil Belajar Siswa Kelas VIII di SMP Negeri 25 Batam Tahun Pelajaran 2013/2014". Skripsi, tidak diterbitkan, Universitas Riau Kepulauan, Batam. 